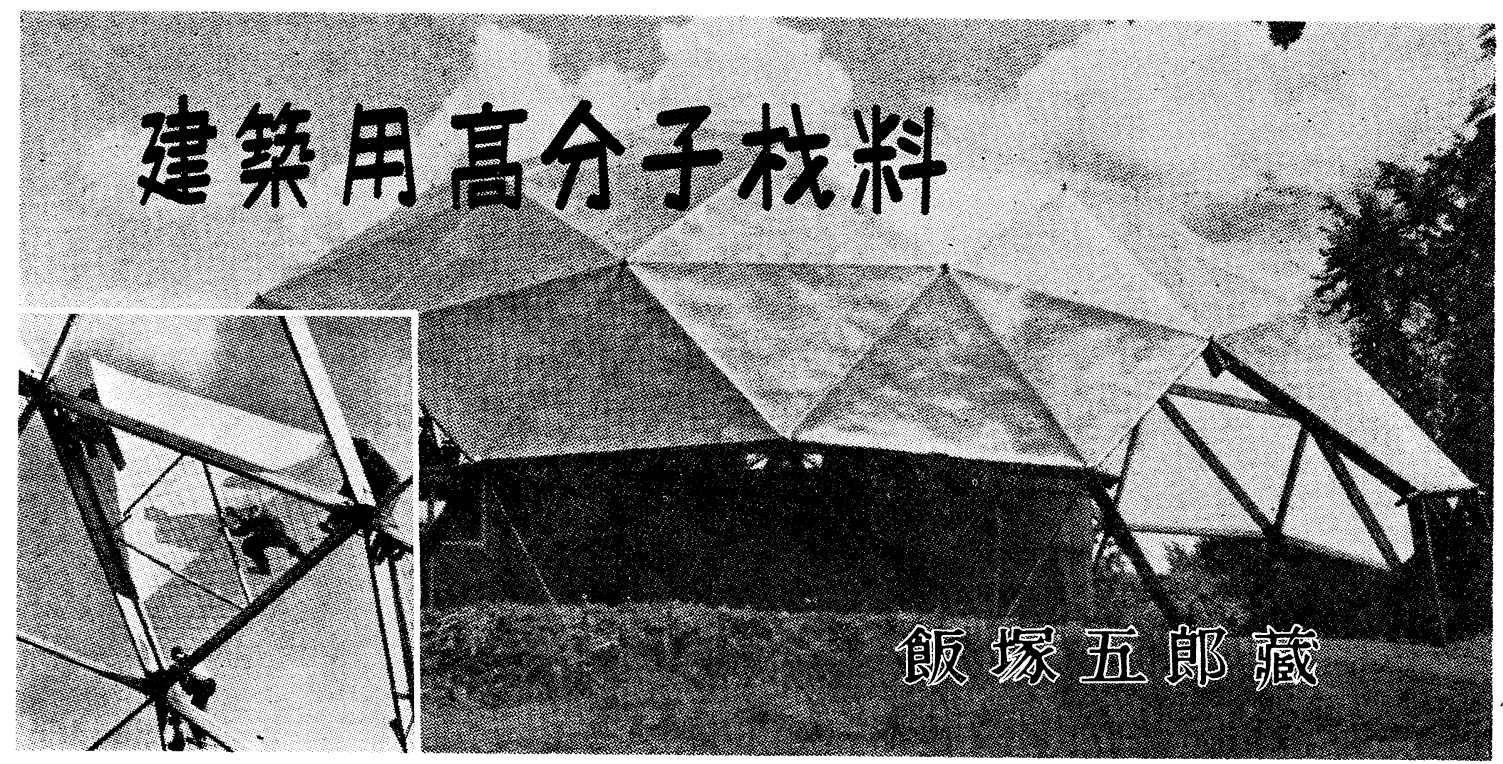

\section{I. 新材料というもの}

建筑はつねに新らしい材料を求めている。それは，今 までの材料のどこかに不満がある場合もあろうし，また， よりすぐれた美しいものを求めていることもある。建築 の進步発達は他のもののように目まぐるしい早さという わけではないが，それでもしばしば草命的な变わりかた を見せるものである。それは，ここ数年來，急に流行し はじめた総ガラスばりの建物や，1階の杜だけをむき出 しにした『裙まくりの建築』を見てもわかる。それでは 今までの建筑樣式はまったく捨ててかえりみないかとい うとなかなかそうではない。建築というものはまた，か なり保守的な面をもっていて，容易にそのメカニズムを 変えない。そ机は主に，その実用面からいえることで， 今までの方式で一応満足できる建築の形式は，それをあ えて改龩し，かえって元も子もなくしてしまうような仜 險をおかさない, といら考え方むある。これは, 建築主 にとってみれば建物は最大の買物であるからだ。このよ らな新旧の争、は，もちろん建築以外にもあることで, 多くの点からの批判に耐えた新しいものがやがては旧い ものにとってかわることになる。

いうまでもなく, 高分子は新しい建築材料の代表選手 だが，上にのべたことはその現狀に例えられ，この材料 の將來を暗示するものといえよう。

\section{II. 積層材料の発達}

いずれにせよ高分子物質の建築への淮出はめざまし い。野心的な建築家にとってこれほど魅力的な材料はあ

カツト：集成木材を骨組とし補强ポリエステル板を被 覆とした建築構造（A.Forum Dec., 1954 より)。 左下：ポリエステル板は厚さ $1 / 16$ " 一辺 12 14'。
るまい。

それらを見わたすと, この材料はメタアクリル樹脂や ビニルフィルムのように單独で使われるということもも ちろん結構だが (1図), ポリエステルやフェノール樹脂 のようにグラスファイバーといっしょになってすぐれた 成型品をつくることもあり $(2$ 図), この方があるいは本 觔の行き方かとも思われる。床材料として盛んに使われ はじめた塩化ビニルまたは瞰睃ビニルと不綿との混合物 もその 1 例であり, 壁材料としてのホモゲンホルッや八 ードボードはいずれも尿素樹脂と木材細片とのコンビネ ーションである $(3$ 図)。これはちょうどセメントという 材料が, 砂とまぜてモルタルをつくり, さらに砂利を入 れてコンクリートとなり，また石綿と混じてアスベスト ボードをつくる，というょうに広い用途をもっているの に似ている。しかもこちらは種類が多く，セメントより 美しく，肌ざわりがよく，軽いというすぐれた点がある。

また，薄いフィルムにして他の材料とはり合わせると

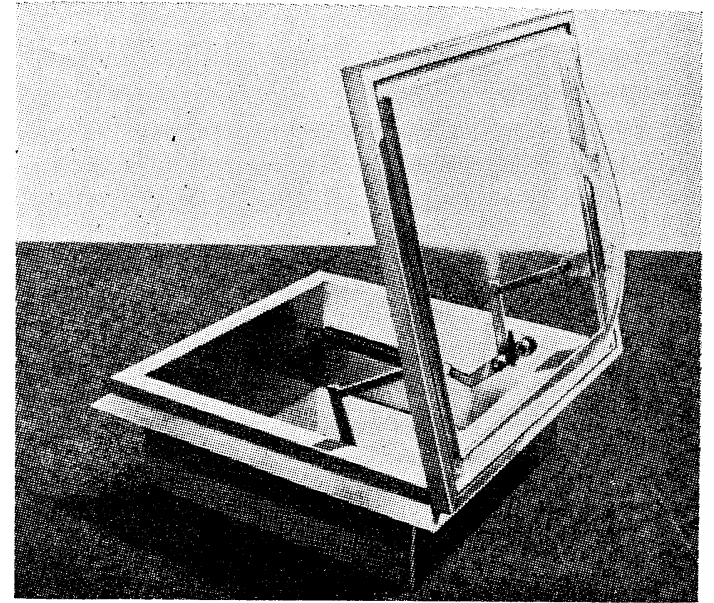

第 1 図 メタアクリル樹脂の探光裝置 


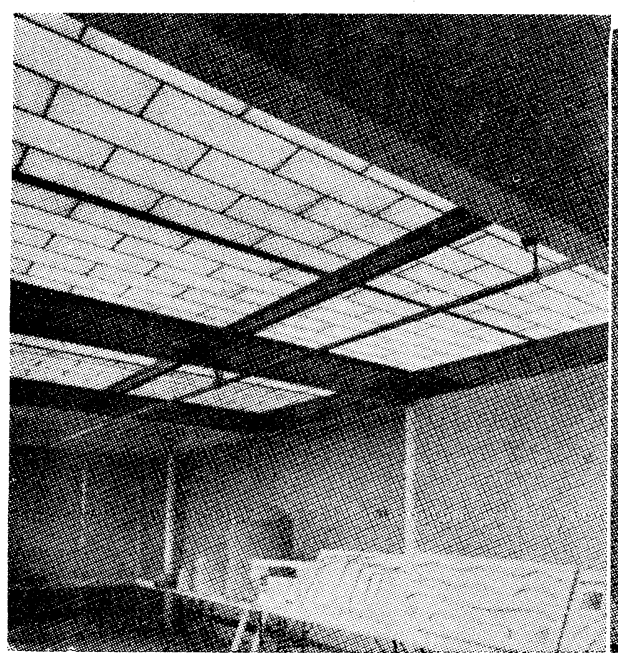

第2図 ポリエステルのスカイライトと

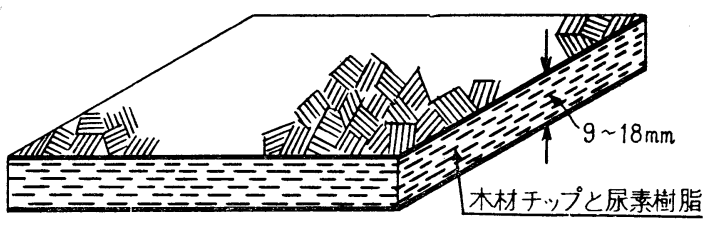

第3図 ホモゲンホルツ

いら方法が盛んに行われる。これは積廨材料（Laminates）にほかならない。この方式はひとり高分子にかぎ らず，現代の工業材料の 1 つの流行とも見られる。筆者 がかって師事した MIT (Massachussetts 工大)の Dietz 㸚授の著書 “Engineering Laminates”に注，積層木

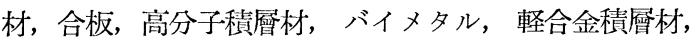
合わせガラスなどあらゆる材料の積層されたものについ
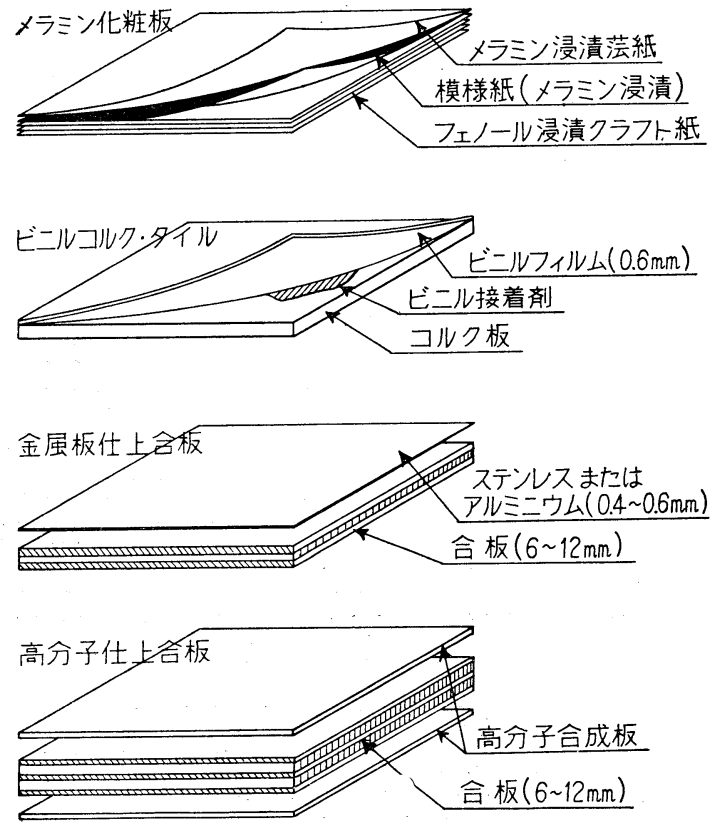

第 4 図 積愿材料の構成
て述ベられている が，この本の開卷は じめに日本刀の橫断 面図をかかげこれ が各種の銅の手のこ んだ積磻材であるこ とを示しているのは 興味深い。

積檿高分子材料の 好例はメラミン化粧 板である。これは， よく知られている通 り,メラミン樹脂を 浸漬した薄い紙を， 同じくメラミンで処 (A. Forum, Jan., 1955 より)

理したプリント模樣紙の上にのせ，厚さを增すためにフ ェノールで処理したクラフト紙数枚を裏に重社て熱圧し たものである。このほか, 外國にはビニルフィルムをコ ルクの上にはりつけた床材料があり，合板の表面に高分 子フィルムを積曆した良質な壁材料もある (4 図)。

このように高分子が主役を 演じなくても, 單にノリとし て働く場合も見のがすことが できない。金属, ガラス, 木 材などを打互に自由にはり合 わせることが，今や可能にな ったのはいずれも高分子ノリ のおかげであって, これらの 積檿材料が建築経済の上から いかに合理的であるかはいう までもない。たとえば木材に 存在する節その他の欠点部分

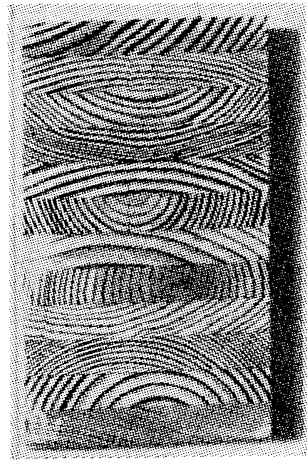

第 5 図 積層木材 をとりのぞいて，良質な部分だけをはり合わせて 5 図の ような「集成本材」をつくることは，米國では盛んに行 われている。わが國でも森林資源の活用といら意味から 研究が進められている。

また，建築の塗裝に打ける役割はもはや欠くことので きないものとなった。今までの天然樹脂系統の塗料に対 して高分子塗料はいろいろな性質のものを自由につくり うる利点をもっている。とくに耐アルカリ性のものがコ ンクリートやプラスターの塗裝に使われはじめたことは 建築塗裝のあり方を一变した感がある。つまりコンクリ ート建筑の仕上げが簡單になり，かついっそう華やかに なった。鉄骨のさび止塗裝についても今までのものよ り完全なものが可能になった。

\section{III. サンドウィッチ・パネル}

以上のように高分子材料は今までおもに建築の仕上げ

Vol. 5 [281] 
に使われてきたが，考えてみるとまだ焦出の分野があり そうである。しかしそれはかならずしも單にコンクリー トや金属や木材ととりかわるといら形ではなくて，場合

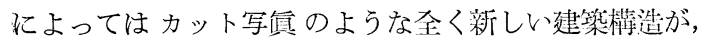
この材料によってうながされることも考えられる。それ は，いまの建築がいろいろな点でもっと改良しなければ ならないところをもっているからである。

まず第 1 に，もっと重量の軽い建物をつくらなければ ならない。日本の大都市は例外なく地盤が吹かく，建物 が沈んだり, 地震に対して不安定だったりするためで, 建物を軽くすれば基檚の構造も簡吡になって非常に有利 である。地盤がよくても欧米のように高懕建築をつくる ときには，なるべく軽い材料を使わないと 1 階などは太 い桂を必罗とし，不経済である。この点では鉄觔コンク リート建築もあまり感心できない。杜，梁のような部材 は仕方がないとしても，壁体は他の材料を使って重量を へらすことが望ましい。また鉄骨蓕造でもその壁材料に 适当なものがない現状である。ここに茼分子材料のよう な軽くて强度の大きいものが活用される余地がある。航 空機材料にすでに盛んに使われていることはこれを襄書 きする。

もら 1 つの建築合琶化の方向は, その權造をなるべく 簡單にするために，材料を十分に工場加工して現場に連 んですぐに取りつけられるようにすることで, これを建 築の工場生座化 (Prefabrication) と呼んでいる。これ

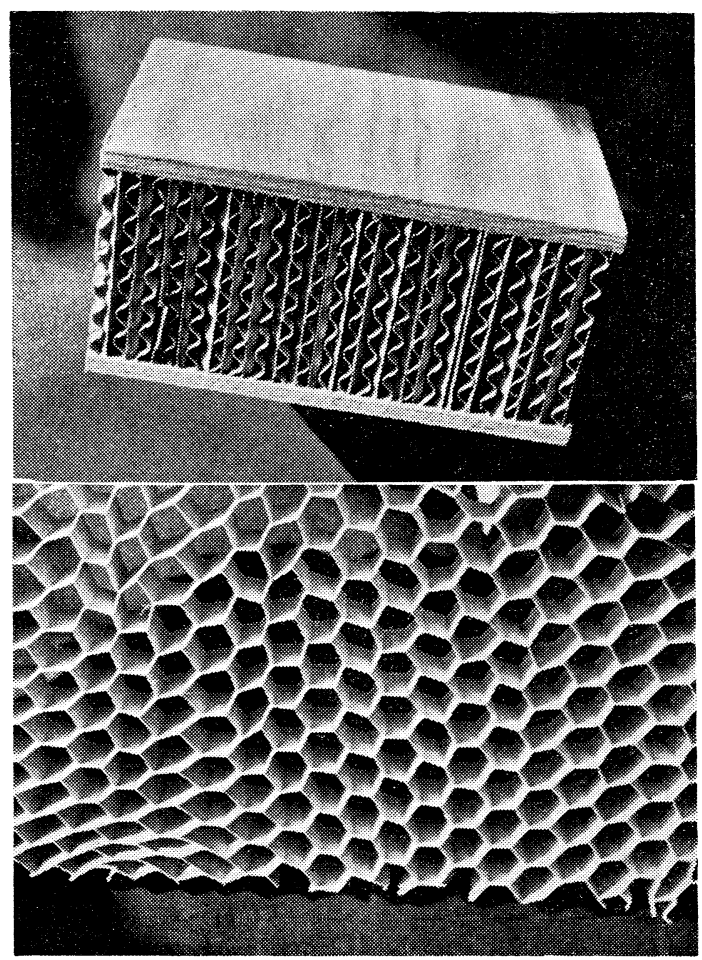

第 6 図 上：ハニカムサンドウィッチ・パネル 下: 蜂巢狀のコア（上とは別然式）

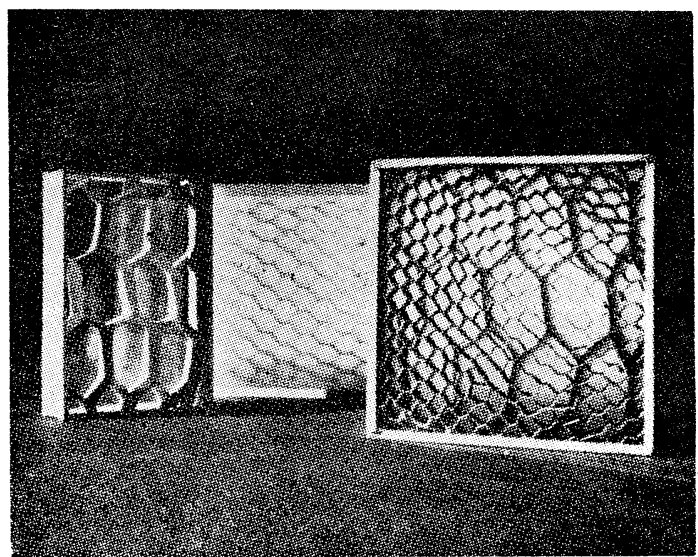

第 7 図 ポリエステルのサンドウィッチ板

(House+hone Feb., 1954 より)

によって材料が合理的に筫約され，工事に姴する人力も 期間もへらすことができる。たとえばコンクリートや淦 り篹のように現場で水でねって施工するものは硬化する のに時間がかかり，次の工事に進めずに待つこともあ る。これも米國の高愿建筑などでは切実な問題で，あの スカイスクレーパーは 1 階ごとにコンクリートを流し込 んでっくってゆくのでは何年かかるかわからない。高層 建築でなくても，人間の労力が貴重になりつつある交明 國では当然，もっと早くできて，手のかからない建築を のぞむわけである。そこであらかじめ工場で單位壁板や 屋根板といったものを, 仕上げまで含めてっくっておき， 現場では水を使わない，いわゆる乾芽造 (Dry Construction) というものが考えられたのである。

以上の 2 つ傾向をみても, 建築單位板といったよう なものが軽くて丈夫な高分子材料でつくられることが望 ましいが，その盟位板の權造として Sandwich Panel といら新型式が登場する。これはすでに米國あたりでは 行われているもので，表䣶には美しさと强度をもった板 狀の材料を配し，內部には筑を遮断するような材料を入 れてサンドウィッチにしたものである。力学的にみてこ のパネルが曲げを受けると両裴面近くに大きな応力が起 るから，この取报いは合理的といえよう。6 図执よび 7 図のようなものは Honeycomb Core と呼ばれ, クラフ ト紙をフェノール樹脂で処理して 耐水性を与えたもの を，波型または蜂の䒩狀にしたものを芯とし，表面には 合板や金属板が使われているが，もちろんここにポリエ ステルなどの価分子材料が利用さるべきである。また芯 には多孔質にした高分子物質を利用することもできる。 これはやはり航空機材料としてまず発達し, 建築に及ん できたものである。この種のパネルは 2 階建までならば それ尚鸟で靽造体となり，杜も梁も使わない建物をつく ることができるし，鉄骨棒造で壁や休に利用することも できる。8 図は多泡プラスチックを芯としたコンクリー ト板のパネルを用いた壁体である。 


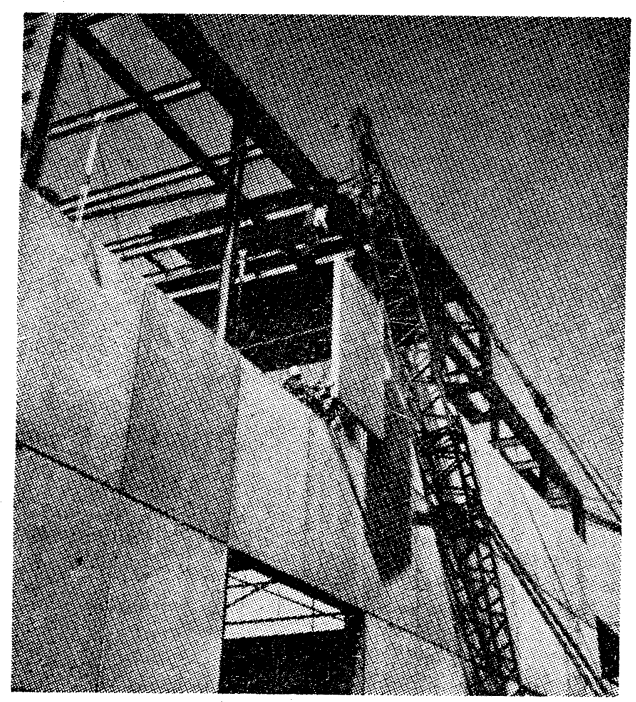

第 8 図 厚さ $13 / 4 "$ のコンクリート板を琅皮とし， $11 / 2$ "厚の多泡スチレン樹脂をコアとしたサン ドウィッチ板 (A. Forum, Jan, 1955 より)

\section{IV. 高分子材料の耐候性}

ところで，高分子材料がこのように広く建築に使われ る場合に問題となることは，その弣久性はごうかという ことである。耐久性といら意味は広いが，ここではその 硬さと耐候性をとりあげてみたい。耐候性（Weatherability）とは外氡にさらされる場合の抵抗力のことであ る。

高分子の引かき硬さ 篗者は Martens 引かき硬度 計で各種の硬質高分子成型品について実臉した ${ }^{1) 。 こ れ ~}$ は先端にダイヤモンドをつけた円錐針によって試料面に きずをつける方法で，円錐針に加える苻車を $5 \mathrm{~g}$ 打き に $50 \mathrm{~g}$ まで霄した各段階の引かききずの巾を測定し たものである。結果は 9 図の通りで，これによれば i) 一般に熱可塑性の高分子は熱硬化性のものにくらべてき ずがつきやすい。ii）試瞼したものの中ではメラミン鼔 脂が一番硬く,フェノール, ニリアがこれについでい

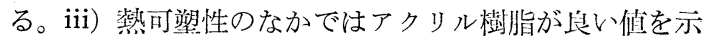
すが，それでもガラスにははるかに劣り，有機ガラスの 利用はこの点に疑間を残している。iv）ポリスチレン， 醀酸セルローズはさらに軟かいという結果を得た。

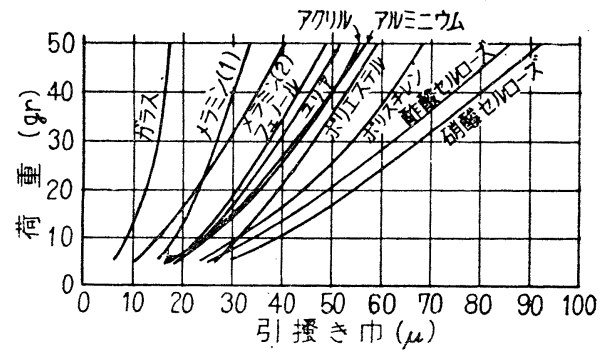

第 9 図 高分子材料の引放き硬さ
高分子材料の耐候性 Yustein らは 17 種の高分子. 成型品について，北はアラスカ $\left(71^{\circ} \mathrm{N}\right)$ から南はパナマ $\left(9^{\circ} \mathrm{N}\right)$ に至る閶の 5 地点で, 3 年閶にわたる曝露試臉を 行い, 引張强さ, 曲げ强さ, 硬さ, 透明度などを測定 し，つぎの結染を得ている2)。i）一般に熱硬化性のもの が熱可塑性のものより强く, 前者の中でも特にメラミン 樹脂のグラスファイバー積曆品がよく, 各地での䀧露結 果で品質の少化が少ない。ii）これにつぎフェノール樹 脂の縕基材積愿品はやや少り, フェノール注型品は 3 年 後には引張り强さが $1 / 2 \sim 1 / 3$ に減っている。 iii) 熱可 塑性のものではアクリル樹脂がよく, ことに外観の变化 はほとんどなく，透明度もわずか減少する程度である。

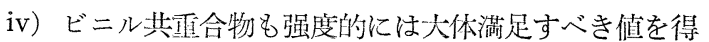
ているが，、わゆる黄化現像があって色は変化する。V) 酷酸セルローズは外観や强さの変化がはげしく, ここで は一翻弱いという結果であった。

なお曝露試驗は地域によってかなり異なった結果を与 え, 高溫のところや海岸地方は紫外線が强く, あるいは 空氯中の塩分も多いので，內陸の普通氣候のところにく らべてはげしい劣化をもたらすといわれている。

つぎに Decoste らは㳄質塩化ビニルを 3 年閒,外氣に さらした結果を発表している3)。これも米國內のフロリ ダ, アリゾナなどを選んで行なったもので, 試譣片の延 び率の減少によって評価している。これによると塩化ビ ニルについては可塑剈, 安定剤はもちろん, 顏料によっ て大いに酎候性を異にすることが明らかとなった。すな わち予備的な実羷では黑い顏料入りのものが强く, 明る い色のものがこれにつぎ，無顏料の透明品が一番弱、。 また白色顏料のけではチタン白が最良で，酸化亞鉛これ につぎ，訟化アンチモンも大休惡くないという。その含 有量は容皘で $2 \%$ ぐらいがもっとも艮好な頝料が多か った。安定剤として二塩基性リン酸鉛を用い，これに可 塑剤として DOP，またはこれとジフェニル・オクチル フォスフェートを用いたものが艮い結果を示している。

日本でもこの種の試噞が, 大阪市工研の大岛, 上田両 氏によって行なわれ，篗者も実崄中であるが，このよう な耐久性が明らかにされてはじめて建築材料としての声 価が定まり，用途もはっきりしてくるというべきであろ う。また最近いわれているような原子力の助けによって きわめて耐久的な高分子材料が使われることも期待され る。ともあれ，高分子材料がいろいろな点で建築の進步 を助け，改革をもたらすであるうことは疑いない。

(横浜國立大学・助敉授)

\section{交献}

1）飯塚：プラスチックスの硬さと耐诶耗性，日本建 築学会研究嗐告, 1954 年. 10 月

2) S. E. Yustein, R. R. Winans and H. I. Stark: ASTM Bull., 196, 29 39 (Feb. 1954)

3) T. B. Decoste and V. T. Wallder: Ind. Eng. Chem., 47, 314 322 (Feb. 1955) 